\title{
Family Leadership Styles and Deviant Behaviours of Primary School Pupils in Enugu State, Nigeria
}

\author{
Eucharia Nchedo Aye ${ }^{1}$, Innocent Kama ${ }^{1}$, Theresa Olunwa Oforka ${ }^{1}$, Celestine Okwudili Eze ${ }^{1}$, \\ Nkiru Christiana Ohia ${ }^{1}$, Ngozi Eucharia Eze ${ }^{1}$, Julia Amobi Onumonu ${ }^{1}$, \\ Ngozi Hope Chinweuba ${ }^{1} \&$ Immaculata Nwakaego Akaneme ${ }^{1}$ \\ ${ }^{1}$ Department of Educational Foundations, University of Nigeria, Nsukka, Nigeria \\ Correspondence: Immaculata Nwakaego Akaneme, Department of Educational Foundations, University of \\ Nigeria, Nsukka, P.M.B.410001, Enugu State, Nigeria. E-mail: immaculata.akaneme@unn.edu.ng
}

Received: May 12, 2019 Accepted: June15, 2019 Online Published: June 27, 2019

doi:10.5539/gjhs.v11n8p113 URL: https://doi.org/10.5539/gjhs.v11n8p113

\begin{abstract}
Objective: This study examined family leadership styles as determinants of deviant behaviours among primary school pupils in Enugu State, Nigeria.
\end{abstract}

Methods: The study adopted a correlational research design. A total of 821 pupils were drawn as the sample for the study. A questionnaire was used as an instrument for the study.

Results: The major findings of the study revealed that primary school pupils exhibited 12 out of 15 types of deviant behaviours such as indulging in exam malpractice, not devoted to studies, Bullying weaker pupils, fighting among pupils, lateness to school, and keeping bad friends among others as identified. It also showed that the authoritarian family leadership style had a significant relationship with primary school pupils' deviant behaviour. Again it was discovered that the authoritative family leadership style also called assertive, democratic or balance family leadership style had a significant relationship with pupils' deviant behaviours negatively. Moreover, permissive family leadership style had also a significant relationship with primary school pupils' deviant behaviours. The result also indicated that neglectful family leadership style had a significant relationship with primary school pupils' deviant behaviours. Furthermore, the result showed that family size had a significant influence on deviant behaviours exhibited by primary school pupils in Enugu state.

Conclusion: Rewarding and praising children who have good behaviours and assigning models to role-play by pupils with deviant behaviours may help to curb deviant behaviours among primary school pupils.

Keywords: family, family leadership styles, deviant behaviours, primaryschool, pupils

\section{Introduction}

The family has been universally perceived as a small but powerful unit and the oldest institution in the history of human existence that helps in the character formation of the child and moulding of the behaviour of the individual in the society. This is because family is the fundamental and basic social unit for human development and also the primary agent for the socialization of children. According to Macionis (2007) family is a social institution found in all societies that unite people in cooperative groups to care for one another including children. A family is a social unit made up of father, mother, children and blood relations (Okonkwo, 2005). Similarly, a family is a unit of people tied by bonds of marriage, birth or adoption, and do have in most cases a common abode. The man and woman as the first members of the family have obligations towards the younger members as they arrive and that involves inculcating social norms such as love, care, cooperation and discipline among her members. When families fail in these basic functions, a faulty foundation is laid which will result in faulty adult behaviours such as corruption and all kinds of indiscipline. In the context of this study, Family can also be seen as a kinship group of two or more persons who live in the same household and are related by marriage or adoption. The family also performs certain functions for its sustainability and wellbeing.

The family performs many functions such as reproduction or procreation, protection and care of young ones, educational functions and provision of shelter (Sunil, 2011). Reproduction or procreation is an essential function which the family performs in all societies. The family along with regulating the sexual behaviour in relation to 
the satisfaction of sexual needs secures a legitimate basis for procreation. This function of the family contributes to the continuity of family and ultimately perpetuates the human race. Family is regarded as an institution par-excellence for the production and rearing of children. No other institution tends to take care of the child like the family; the child at birth is completely helpless and may not survive without the help of the family. Sunil (2011) asserted that family provides care, protection, security and fulfils other needs to make the child fit in the society. The author also asserted that all the members of the family depend on the home for comfort, protection and peace.

The family also performs educational functions such as socialization of the child that starts from the home through interaction with the parents, sibling and peers. The child learns a lot in the home before school age. Shankar (2012) posited that the performance of the child depends on the family background. It is within the family that the child learns about traditions, customs, norms, and values of the society in which they belong. Highlighting further, the author stated that if any dysfunction is seen in the family system, the functions of the family can be affected. Several family factors determine the functionality and dysfunction of the family. These factors include family structure, family size, and family leadership style.

Family factors are often referred to as those characteristics that define the families and the specific things that make up the family such as family structure, family size, family leadership styles, disciplinary practices and parental involvement among others (Henderson \& Mapp, 2002). Contributing to the above assertion, Benokraitis (2007) maintained that family structure is considered as a family support system involving two married individuals providing care and stability for their biological offspring. Family structures can also be seen as substantial makeup of the members in relation to each other without respect to roles and function (Toby, 2015). In the context of this work, family structure can be referred to as various components that make up the family system such as father, mother and their children. It can also be referred to as households consisting of two married parents and their biological children or their members who are related by blood, marriage, and adoption in extended family ties.

The family has many structures/types, namely, nuclear and extended. The nuclear family comprised of the man, the wife and their children in a monogamous relationship (Anyanwu \& Ofordile, 2012). This implies a relationship that binds the father and the members of the household. Supporting the above assertion, Toby (2015) stated that nuclear family consisted of a father, mother, and their biological or adoptive descendants, often called the traditional family. From the above assertion nuclear family is the type of family which consists of the father, mother and their children while in Extended family, the members include the husband, wife, children and other relations covering two to three generations (Anyanwu \& Ofodile, 2012). Stressing further, the authors, asserted that extended family system consists of the husband, wife, children, grandparents, uncles, aunts, cousins from both sides. Furthermore, Ngale (2009) maintained that children who found themselves in an extended family may experience overcrowding as a result of a large family size which tends to result to low parental attention, financial hardship and this may lead the children into deviant behaviour.

Family size is the number of parents and children that make up a family, either nuclear or extended family (Farrington \& Loeber, 1999). According to Bjorklund (2004), family size refers to all siblings present in a household. Family size can also be seen as the total number of people found in the family. A family may be regarded as large size when the family members are within 7-10 and above 10, while a family may also be regarded as small when the size of family members are within 1-3 and 4-6 respectively (Arthur, 2005). This implies that family size might increase the risk of a child's deviant act. For instance, as the number of siblings in a household increases, the amount of parental attention that can be given to each child may decrease. Also, as the number of siblings increases, the household tends to become crowded, possibly leading to an increase in financial hardship, and frustration (Kantarevic \& Mechoulan, 2006). The reason why family size may be linked to negative behaviours or deviant activities includes absentee parents, financial hardship and broken homes (Ngale, 2009). Thus, it may appear that the larger the number of children in the family, the more they exhibit deviant behaviours. From the foregoing, the researchers may view that the more the number of children in a family, the less time, energy, and financial resources parents will have to devote to each individual child. The family also is posed with a certain leadership style that governs its members.

Besides the above variables (family structure and family size) so far discussed that may affect the behaviour and socialization of children or family members, the family is also posed with certain leadership styles that parents use in training their family members. Family leadership style is the aggregate of the various patterns which parents use in the upbringing, training and rearing of their children (Okpako, 2004). In other words, family leadership styles are the methods which parents use in training their children. It is also known as parenting styles 
or child-rearing practices. In the context of this study, family leadership styles are the different types of practices parents use to socialize their children to internalize acceptable norms and values of the society that will help to mould their personality and behaviour.

Highlighting further on family leadership styles, Baumrind (1972) identified four family leadership styles to include authoritarian family leadership style, authoritative family leadership style, permissive family leadership style and neglectful family leadership style. Authoritarian family Leadership Style is perceived as a family leadership style in which all the decisions and directives made are passed to subordinates who are expected to carry out these under very close supervision (Annick, 2002). Stressing further, Annick maintained that any subordinates' attempt at questioning the directives given are discouraged including the fact that there may be little or no opportunity for subordinates to develop initiative and creativity.

Families that adopt authoritarian family leadership style are characterized by high expectations of conformity and compliance to family rules and directions. Authoritarian family leadership style is a restrictive, punitive style in which parents exhort the child to follow their directions and to respect their work effort (Dienye \& Oyet, 2011). Authoritarian parents are less responsive to their children's needs and are more likely to spank a child rather than discuss the problem (Tim, 2007). Stressing further, the author stated that authoritarian parents display little warmth and are highly controlling. Authoritarian parents exercise authority such as "you will do this because I said so" and "because I'm the parent and you are not". Authoritarian parents do not engage in discussion with teens and family rules and standards are not debated. Authoritarian parents also believed that the children should accept their rules and regulations without question, children of such parents may tend to learn that following parental rules and adherence to strict discipline is valued over independent behaviour. In a related view, Kopko (2007) opined that children may become rebellious and might display aggressive behaviours and as well may become dependent. These children who are more submissive tend to remain dependent on their parents.

Authoritative family leadership style also called assertive, democratic or balanced family leadership style (Dienye \& Oyet, 2011), is characterized by a child-centred approach that holds high expectations of maturity. Authoritative family leadership style understands their children's feeling and teaches them how to regulate them. They encourage children to be independent but still places limits and controls on their actions. Authoritative parents set limits and demand maturity, but when punishing a child, the parents will explain the motive for their punishment (Tim, 2007). Children under this type of family leadership style tend to display positive behaviour. According to Santrock (2006), children of authoritative parents tend to be cheerful, self-reliant, self-controlled, friendly and achievement-oriented, co-operate with adults and cope well with stress.

Permissive family leadership style involves allowing the children to do what they wish. Permissive family leadership style also called indulgent family leadership style is a style of family leadership in which parents are very involved with their children, place few demands or controls on them (Dienye \& Oyet, 2011). In using this style, the parents are nurturing and accepting and are very responsive to their children's needs and wishes. Justifying the above assertion, Santrock (2006) postulated that permissive parents do not require children to regulate themselves. Buttressing further, the authour noted that Children from such parents tend to be rebellious, low in self-reliance and self-control, impulsive, aggressive, domineering, aimless, and low in achievement.

Neglectful family leadership style also known as uninvolved detached, family leadership style involves parents that exhibit low control, and are not involved in their child's life, are disengaged, undemanding, low in responsiveness and do not set limits (Nwachukwu, 2001). Contributing to the above idea, (Tim, 2007) stated that parents of neglectful family are unsupportive of their children but will still provide basic needs. Children of neglectful parents tend to "be socially incompetent, have low self-esteem, impulsive and aggressive, poor self-control and do not handle independence well, have difficulty in determining right or wrong behaviour and experience school problems" both academic and behavioural (Terry, 2004).

In other words, when there is any form of dysfunction in the family system, the resultant effect tends to be seen in the behaviours exhibited by the child/children. According to Merriam (2013), behaviour refers to the way in which one acts or conducts one's self in response to stimuli. From the foregoing, behaviour can also be defined as the way in which an animal or a person acts in response to a particular situation, stimuli or towards others. Any conduct or behaviour which does not conform to the accepted cultural norms of the society is known as deviance. Deviance is recognized as a violation of cultural norms (Macionis, 2007). In consonance with the above assertion, Richard (2009) opined that deviance is the act of being different from the popular belief usually in a bad way. Buttressing further, the authour stated that deviance is an act or behaviour that does not conform to accepted norms and values of the society and rules and regulations guiding an organization or institution in the 
society. When an individual behaviour is at variance with the existing norms, he or she could be described as a deviant. Justifying the above assertion, Wisegeek (2013) maintained that deviant behaviours can be referred to as behaviours which do not adhere to widely-accepted social or cultural norms. Deviant behaviour is considered abnormal or anti-social if it is uncommon, different from the norm and does not conform to what society expects (Nwankwo, 2006). In the context of this work, deviant behaviour is an act which is contrary or at variance with the socially accepted norms and values such as stealing, fighting, bullying, telling lies, absenteeism among others.

There are different forms of deviant behaviours which include a physical form of deviance, criminal form of deviance, moral form of deviance and psycho-social form of deviance. The physical form of deviance is perhaps the most visible form of deviance and it can evoke stereotypes, stigmatization, and discrimination. Sociologists have described two types of physical deviance including; violations of aesthetic norms (what people should look like, including height, weight, and the absence or presence of disfigurement), and physical incapacity, which include those with a physical disability (Goode, 2005). According to Nzekwu (2011), the criminal form of deviance are offences that are destructive to life and property and requires prompt attention because of their harmful nature and the gravity of the behaviour, their significant departure from that which is normal and acceptable in both the school community and the larger society. Ibia (2006) stated that criminal offences are great offences against societal laws and hence must be repressed and controlled in accordance with the established rules and regulations governing the school system and the laws governing the larger society. Stressing further, the author enumerated the example of the criminal form of deviance to include suicide, exam malpractice, stealing, forgery, fighting, fraud and assault. Moral form of deviance can be defined as the deviation from society's moral values. The behaviour negates the moral norms in the society. Examples of moral deviance are sexual perversion, alcoholism, drug use, rape, and such behaviours are rampant amongst children and teenagers (Nzekwu, 2011). From the foregoing, it could be deduced that deviant behaviours exhibited by primary school pupils may include stealing, picking pocket, fighting, quarrelling, lateness, loitering about, lying, gossiping, noise making, among others which may be caused by some factors such as poor parent-child relations among others.

The causes of deviant behaviours among primary school pupils may be associated with poor parent-child relations, (poor supervision, lack of discipline, low parental involvement in the training of the child, low parental warmth), and psychological factors (daring, impulsiveness, poor concentration), family structure/type, family size, child neglect, parental conflict and disrupted families (Lipsey \& Derzon, 1998). Alienation, negative labelling, social bonds amongst others may also be causes of deviant behaviours. Murray and Farrington, (2005) opined that family may be an important factor for pupils' deviant behaviours. In addition, pupils' from broken families tend to have deviant behaviours. Cheng (2001) also maintained that Family factors may also cause deviant behaviours of pupils. There are also other causes which include environmental and psychological factors.

From the above causes of deviant behaviours among primary school pupils, it may be seen that in spite of deviant acts emanating from family factors such as family structure, family size, family leadership styles, other factors such as environmental and psychological factors may also have been influencing deviant behaviours with its attendant consequences. Supporting the above assertion, Sanjana (2008) described children who exhibit deviant behaviours as children with a moral problem, lack of respect for traditional values, lack of self-respect, lack of independence and self-sufficiency which have serious consequences on them and the society at large. Buttressing further, Sanjana stated that children with deviant behaviours potentially lose chances of fulfilling their life ambitions and career and as such constitute problems to the society. These deviant behaviours have severe or serious consequences on pupils and society at large. Deviant behaviours might affect the individual and society at large in the area of socialization, academics, character formation and life ambitions among others, which may lead the child to become societal nuisance terrorizing the lives of other members of the society in general.

The researchers' observation has shown that parents in Awgu education zone are mostly farmers and businessmen and women whose aim is to acquire wealth through their farm produce at the end of the harvest season and for the business class who equally aims at making "quick money". As a result of these, parents handover the training of their children and wards to housekeepers and nannies without proper supervision of their children's behaviour or character formation, food, health and academic works such as assignment given to them in schools. In Awgu Education Zone, personal observation as a result of a visit to some primary schools have shown that pupils in the primary schools are late to school, fight each other, involve in examination malpractice. Also, some of the pupils steal other pupils' money and books; they tell lies and make a lot of noise in the classroom. Some of the pupils are used to loitering during school hours, some even roam along the street 
when lessons are going on in the school, and some of them spend so much money during the break period, buying things for themselves and their friends which is an indication that the money they are spending might have been stolen from their parents. The pupils' extravagant spending is not known by their parents. These negative behaviours may have a serious impact on their education and social lives which in turn will affect the society at large. The pupils may be distracted and have a low concentration in the classroom thereby leading to failure or low academic performance.

These pupils who indulge in these deviant behaviours may graduate from stealing to an armed robbery in future and become a terror to the family, community and society at large. However, whether family factors such as family structure/types, family size, and family leadership styles influence deviant behaviours among pupils in primary schools in Awgu Education Zone, Enugu State is yet to be ascertained. Primary school pupils are children from the age of 6 years to 11 years that receives elementary or primary education coming before secondary school and after preschool. This implies that primary school pupils are children that have finished nursery education who are being taught in preparation for secondary education. Primary education is the kind of education which is given to children from age $6+$ to about 10 or 11 years, it is an educational training provided to school-age children from primary 1-6 (Umemetu \& Ogbonna, 2013). At this stage, the education they receive is compulsory in most part of the world. Primary education, in particular, is the level of education that develops in the individual the capacity to read, write and calculate. Bruns, Mingat \& Rakotamalala (2003) stated that it helps to eradicate illiteracy, which is one of the strongest predictors of poverty. Justifying the above assertion, UNESCO (2001) posited that this explains why primary education is the largest sub-sector of any education system and offers the unique opportunity to contribute to the transformation of societies through the education of the young ones. It is against this background that the researchers are interested in investigating family factors as determinants of deviant behaviours among primary school pupils in Awgu Education Zone of Enugu State.

\section{Methods}

The design of this study was a correlational research design. The study was carried out in primary schools in Awgu education zone of Enugu State. Awgu education zone is made up of three local government areas which include: Awgu, Aninri, Oji-River Local Government Areas. The population of the study comprised of all the public primary six pupils in Awgu education zone of Enugu state. The population of the study was four thousand six hundred and four 4,604 primary six pupils in the education zone (Annual School Census, Universal Basic Education Board, (UBEB) Enugu (2014). Of this total of 4,604 pupils from the zone, Agwu local government area has one thousand six hundred and seventeen $(1,617)$ primary six pupils with seventy-two (72) public primary schools, Aninri local government area has one thousand nine hundred and eighty $(1,980)$ primary six pupils with (67) public primary schools, Oji-River local government area has one thousand seven (1007) with (69) public primary schools and primary six pupils respectively (Annual School Census, Universal Primary Education Board ( UBEB) Enugu, 2014).

A sample size of 821 primary six pupils in all the public schools in Awgu education Zone representing $20 \%$ of the target population was drawn comprising pupils around public schools in the local government Areas of Awgu education Zone using the multistage sampling technique. In the first stage, a simple random sampling technique was used to draw two towns each from the three LGAs in the Zone. In the second stage, the proportionate stratified sampling technique was used to draw pupils from public schools in six towns. Proportionate sampling technique was used because the numbers of pupils in the six public schools are not the same. Thus a total of 100 pupils from the first town, 130 pupils from the second town, 130 from the third town, 155 from the fourth town, 150 from the fifth town and 156 from the sixth town in the selected public schools in the above towns were drawn making a total of 821 respondents for the study.

The instrument for data collection in this study was a structured questionnaire titled family factors and deviant behaviours questionnaire (FFDBQ). To ascertain the face validity of the family factors and deviant behaviours questionnaire (FFADBQ), the researchers gave the initial draft to three experts for validation. To test the reliability of the instrument, a trial test procedure was adopted. The instrument was administered to twenty pupils of a community primary school outside the study area. Data collected were subjected to the test of internal consistency using Cronbach alpha procedure. This gave the reliability coefficient value of 0.82 for section $\mathrm{B}$, section $\mathrm{C}$ was made up of four clusters, $\mathrm{A}, \mathrm{B}, \mathrm{C}$, and $\mathrm{D}$, with reliability coefficient values of $0.78,0.83,0.75$ and 0.79 respectively with an overall reliability coefficient value of 0.79 . Finally, section D had a reliability coefficient value of 0.85 .

Twenty (20) copies of the instrument were administered directly to the respondents by the researchers and two research assistants. The data collected were analyzed in different stages. In the first stage, research questions one, 
six and seven were answered using mean and standard deviation while the Pearson product moment correlation coefficient was employed in answering research questions two, three, four and five. The null hypotheses, one, two, three, and four were tested using multiple regression analysis while ANOVA was used to test hypotheses five. The decision benchmark was 2.50. This implies that any item that is rated 2.50 and above was accepted while any item below 2.50 was rejected.

\section{Results}

\subsection{Research Question 1}

What are the types of deviant behaviours exhibited by primary school pupils?

Table 1. Mean and Standard deviation of the types of deviant behaviours exhibited by primary school pupils

\begin{tabular}{lllll}
\hline S/N & & $\bar{x}$ & SD & DEC \\
& & & & \\
\hline 1 & Indulging in exam malpractices & 2.57 & 0.50 & Accepted \\
2 & Not devoted to studies & 2.60 & 0.49 & Accepted \\
3 & Bullying weaker pupils & 2.70 & 0.56 & Accepted \\
4 & Fighting among pupils & 2.58 & 0.51 & Accepted \\
5 & Lateness to school & 2.72 & 0.45 & Accepted \\
6 & Keeping bad friends & 2.85 & 0.53 & Accepted \\
7 & Stealing among pupils & 2.58 & 0.60 & Accepted \\
8 & Gossiping among pupils & 2.77 & 0.43 & Accepted \\
9 & Quarrelling between each other & 2.63 & 0.49 & Accepted \\
10 & Telling lies to fellow pupils, teachers and parents. & 2.48 & 0.50 & Accepted \\
11 & Loitering during school hours. & 2.73 & 0.45 & Accepted \\
12 & Absent to school. & 2.67 & 0.51 & Accepted \\
13 & Using of hard drug. & 1.77 & 0.45 & Rejected \\
14 & Smoking Indian hemp. & 1.80 & 0.48 & Rejected \\
15 & Consumption of alcohol. & 1.89 & 0.31 & Rejected \\
\hline
\end{tabular}

Result in Table 1 shows the mean and standard deviations of respondents on the types of deviant behaviours exhibited by primary school pupils. Table 1 indicates that the mean values for the items ranged from 1.11 (item 13) to 2.85 (item6) for the types of deviant behaviours exhibited by primary school pupils. The mean values of items 1 , $2,3,4,5,6,7,8,9,11$ and 12 were above 2.50 criterion value. This implies that primary school pupils agreed that they exhibited all these deviant behaviours. Table 1 equally show that the mean values of items 10,13, 14 and 15 below $2.5 \mathrm{~s} 0$ criterion value, indicating that these deviant behaviours are not exhibited by primary school pupils. This implies that the primary school pupils exhibited 12 different types of deviant behaviours and do not exhibit 3 different types of deviant behaviours.

\subsection{Research Question 2}

What is the relationship between authoritarian family leadership style and deviant behaviours exhibited by primary school pupils?

Table 2. Pearson's Product Moment Correlation Analysis of the relationship between authoritarian family leadership style and deviant behaviours exhibited by primary school pupils

\begin{tabular}{|c|c|c|c|c|c|}
\hline Variable & $\bar{x}$ & SD & $\mathbf{N}$ & $\mathbf{r}$ & $\mathbf{R}^{2}$ \\
\hline deviant behaviours & 37.33 & 3.67 & 821 & 0.97 & 0.94 \\
\hline authoritarian family leadership style & 38.15 & 3.48 & & & \\
\hline
\end{tabular}

$\alpha=0.05, \mathrm{R}^{2}=$ coefficient of determination. 
The result in Table 2 is correlation coefficients of the relationship between authoritarian family leadership style and deviant behaviours exhibited by primary school pupils. Results showed that the correlation between authoritarian family leadership style and deviant behaviours exhibited by primary school pupils was 0.97 . This means there was a very strong positive relationship between authoritarian family leadership style and deviant behaviours exhibited by primary school pupils. The coefficient of determination associated with 0.97 is 0.94 . The coefficient of determination (0.94) also known as the predictive value means that $94 \%$ of authoritarian family leadership style accounted for the variation in deviant behaviours exhibited by primary school pupils. This is an indication that $6 \%$ of the variation in deviant behaviours exhibited by primary school pupils is attributed to other factors other than authoritarian family leadership style.

\subsection{Hypothesis 1}

Authoritarian family leadership style has no significant relationship with deviant behaviours exhibited by primary school pupils in Awgu Education Zone of Enugu State.

Table 3. Regression Analysis of authoritarian family leadership style and deviant behaviours exhibited by primary school pupils

\begin{tabular}{llllll}
\hline Mode & Sum of Squares & Df & Mean Square & F & Sig. \\
\hline Regression & 10371.056 & 1 & 10371.056 & 1.2114 & .000 \\
Residual & 701.499 & 819 & .857 & & \\
Total & 11072.555 & 820 & & & \\
\hline
\end{tabular}

$\alpha=0.05$

In order to test hypothesis $1\left(\mathrm{H}_{\mathrm{O} 1}\right)$, regression analysis was used. The result in Table 3 shows that an F-ratio of 1.211 with an associated exact probability value of 0.00 was obtained. This exact probability value of 0.00 was less than 0.05 level of significance set as a benchmark and it was found to be significant. The null hypothesis which stated that Authoritarian family leadership style has no significant relationship with deviant behaviours exhibited by primary school pupils in Awgu Education Zone of Enugu State was therefore rejected and inference drawn was that authoritarian family leadership style has a significant relationship with deviant behaviours exhibited by primary school pupils in Awgu Education Zone of Enugu State.

\subsection{Research Question 3}

What is the relationship between authoritative family leadership style and deviant behaviours exhibited by primary School pupils?

Table 4. Pearson's Product Moment Correlation Analysis of authoritative family leadership style and deviant behaviours exhibited by primary School pupils

\begin{tabular}{|c|c|c|c|c|c|}
\hline Variable & $\bar{x}$ & SD & $\mathbf{N}$ & $\mathbf{r}$ & $\mathbf{R}^{2}$ \\
\hline deviant behaviours & 37.33 & 3.67 & 821 & 0.79 & 0.62 \\
\hline authoritative family leadership style & 38.52 & 3.75 & & & \\
\hline
\end{tabular}

$\mathrm{R}^{2}=$ coefficient of determination.

The result in Table 4 is correlation coefficients of the relationship between authoritative family leadership style and deviant behaviours exhibited by primary school pupils. Results showed that the correlation between authoritative family leadership style and deviant behaviours exhibited by primary school pupils was 0.79 . This means there was a very strong positive relationship between authoritative family leadership style and deviant behaviours exhibited by primary school pupils. The coefficient of determination associated with 0.79 is 0.62 . The coefficient of determination (0.62) also known as the predictive value means that $62 \%$ of authoritative family leadership style accounted for the variation in deviant behaviours exhibited by primary school pupils. This is an indication that $38 \%$ of the variation in deviant behaviours exhibited by primary school pupils is attributed to other factors other than the authoritative family leadership style. 


\subsection{Hypothesis 2}

Authoritative family leadership style has no significant relationship with deviant behaviours exhibited by primary school pupils in Awgu Education Zone of Enugu State.

Table 5. Regression Analysis of authoritative family leadership style and deviant behaviours exhibited by primary school pupils

\begin{tabular}{lccccc}
\hline Model & Sum of Squares & df & Mean Square & F & Sig. \\
\hline Regression & 6832.670 & 1 & 6832.670 & 1.3203 & .000 \\
Residual & 4239.885 & 819 & 5.177 & & \\
Total & 11072.555 & 820 & & \\
\hline
\end{tabular}

$\alpha=0.05$.

In order to test hypothesis $2\left(\mathrm{H}_{\mathrm{O} 2}\right)$, regression analysis was used. The result in Table 5 shows that an F-ratio of 1.32 with an associated exact probability value of 0.00 was obtained. This exact probability value of 0.00 was less than 0.05 level of significance set as a benchmark and it was found to be significant. The null hypothesis which stated that Authoritative family leadership style has no significant relationship with deviant behaviours exhibited by primary school pupils in Awgu Education Zone of Enugu State was therefore rejected and inference drawn was that Authoritative family leadership style has a significant relationship with deviant behaviours exhibited by primary school pupils in Awgu Education Zone of Enugu State.

\subsection{Research Question 4}

What is the relationship between permissive family leadership style and deviant behaviours exhibited by primary school pupils?

Table 6. Pearson's Product Moment Correlation Analysis of permissive family leadership style and deviant behaviours exhibited by primary School pupils

\begin{tabular}{llllll}
\hline Variable & $\bar{x}$ & SD & $\mathbf{N}$ & $\mathbf{r}^{2}$ & $\mathbf{R}^{\mathbf{2}}$ \\
\hline deviant behaviours & 37.33 & 3.67 & 821 & 0.89 & 0.80 \\
authoritative family leadership style & 36.50 & 3.56 & & & \\
\hline
\end{tabular}

$\mathrm{R}^{2}=$ coefficient of determination.

The result in Table 6 is correlation coefficients of the relationship between permissive family leadership style and deviant behaviours exhibited by primary school pupils. Results showed that the correlation between permissive family leadership style and deviant behaviours exhibited by primary school pupils was 0.89 . This means there was a very strong positive relationship between permissive family leadership style and deviant behaviours exhibited by primary school pupils. The coefficient of determination associated with 0.89 is 0.80 . The coefficient of determination (0.80) also known as the predictive value means that $80 \%$ of permissive family leadership style accounted for the variation in deviant behaviours exhibited by primary school pupils. This is an indication that $20 \%$ of the variation in deviant behaviours exhibited by primary school pupils is attributed to other factors other than permissive family leadership style.

\subsection{Hypothesis 3}

Permissive family leadership style has no significant relationship with deviant behaviours exhibited by primary school pupils in Awgu Education Zone of Enugu State. 
Table 7. Regression Analysis of permissive family leadership style and deviant behaviours exhibited by primary school pupils

\begin{tabular}{llllll}
\hline Model & Sum of Squares & Df & Mean Square & F & Sig. \\
\hline Regression & 8849.160 & 1 & 8849.160 & 3.2603 & .000 \\
Residual & 2223.395 & 819 & 2.715 & & \\
Total & 11072.555 & 820 & & & \\
\hline
\end{tabular}

$\alpha=0.05$.

In order to test hypothesis $3\left(\mathrm{H}_{\mathrm{O}}\right)$, regression analysis was used. The result in Table 7 shows that an F-ratio of 3.26 with an associated exact probability value of 0.00 was obtained. This exact probability value of 0.00 was less than 0.05 level of significance set as a benchmark and it was found to be significant. The null hypothesis which stated that permissive family leadership style has no significant relationship with deviant behaviours exhibited by primary school pupils in Awgu Education Zone of Enugu State was therefore rejected and inference drawn was that permissive family leadership style has a significant relationship with deviant behaviours exhibited by primary school pupils in Awgu Education Zone of Enugu State.

\subsection{Research Question 5}

What is the relationship between neglectful family leadership style and deviant behaviours exhibited by primary school pupils?

Table 8. Pearson's Product Moment Correlation Analysis of neglectful family leadership style and deviant behaviours exhibited by primary School pupils

\begin{tabular}{llllll}
\hline Variable & $\bar{x}$ & SD & N & r & $\mathbf{R}^{2}$ \\
\hline deviant behaviours & 37.33 & 3.67 & 821 & 0.85 & 0.73 \\
authoritative family leadership style & 35.35 & 3.94 & & & \\
\hline
\end{tabular}

$\mathrm{R}^{2}=$ coefficient of determination.

The result in Table 8 is correlation coefficients of the relationship between neglectful family leadership style and deviant behaviours exhibited by primary school pupils. Results showed that the correlation between neglectful family leadership style and deviant behaviours exhibited by primary school pupils was 0.85 . This means there was a very strong positive relationship between neglectful family leadership style and deviant behaviour exhibited by primary school pupils. The coefficient of determination associated with 0.85 is 0.73 . The coefficient of determination (0.73) also known as the predictive value means that $73 \%$ of neglectful family leadership style accounted for the variation in deviant behaviours exhibited by primary school pupils. This is an indication that $27 \%$ of the variation in deviant behaviours exhibited by primary school pupils is attributed to other factors other than neglectful family leadership style.

\subsection{Hypothesis 4}

Neglectful family leadership style has no significant relationship with deviant behaviours exhibited by primary school pupils in Awgu Education Zone of Enugu State.

Table 9. Regression Analysis of neglectful family leadership style and deviant behaviours exhibited by primary school pupils

\begin{tabular}{llllll}
\hline Model & Sum of Squares & df & Mean Square & F & Sig. \\
\hline Regression & 8056.689 & 1 & 8056689 & 2.1883 & .000 \\
Residual & 3015.866 & 819 & 3.682 & & \\
Total & 11072.555 & 820 & & & \\
\hline
\end{tabular}

$\alpha=0.05$. 
In order to test hypothesis $4\left(\mathrm{H}_{\mathrm{O} 4}\right)$, regression analysis was used. The result in Table 9 shows that an F-ratio of 2.19 with an associated exact probability value of 0.00 was obtained. This exact probability value of 0.00 was less than 0.05 level of significance set as a benchmark and it was found to be significant. The null hypothesis which stated that neglectful family leadership style has no significant relationship with deviant behaviours exhibited by primary school pupils in Awgu Education Zone of Enugu State was therefore rejected and inference drawn was that neglectful family leadership style has a significant relationship with deviant behaviours exhibited by primary school pupils in Awgu Education Zone of Enugu State.

\subsection{Research Question 6}

What is the influence of family size on deviant behaviours among primary school pupils?

Table 10. Mean and Standard Deviation of the influence of family size on deviant behaviours among primary school pupils

\begin{tabular}{llll}
\hline Family Size & $\mathrm{N}$ & $\bar{x}$ & $\mathrm{SD}$ \\
\hline 1-3 Children & 122 & 2.30 & 0.33 \\
4-6 Children & 358 & 2.46 & 0.24 \\
7-10 Children & 225 & 2.58 & 0.14 \\
Above 10 Children & 116 & 2.61 & 0.16 \\
\hline
\end{tabular}

Result in Table 10 shows the influence of family size on deviant behaviours among primary school pupils. Result shows that those from the family of within 1-3 children had mean score of 2.30 with a standard deviation of 0.33 , those from 4-6 children had mean score of 2.36 with a standard deviation of 0.24 , those from 7-10 children had mean score of 2.58 with a standard deviation of 0.14 while those with above 10 children had mean ratings of 2.61 with a standard deviation of 0.16 . The result showed that the children from small family size had a lower mean rating on deviant behaviours whereas those from large family size had higher mean ratings. This is an indication that family size had an influence on deviant behaviours among primary school pupils.

\subsection{Hypothesis 5}

Family size has no significant influence on deviant behaviours exhibited by primary school pupils in Awgu Education Zone of Enugu State.

Table 11. ANOVA of the influence of family size on deviant behaviours among primary school pupils

\begin{tabular}{lccccc}
\hline & Sum of Squares & df & Mean Square & F & Sig. \\
\hline Between Groups & 8.241 & 3 & 2.747 & 54.777 & 0.00 \\
Within Groups & 40.971 & 817 & .050 & & \\
Total & 49.211 & 820 & & \\
\hline
\end{tabular}

$\alpha=0.05$.

Result in Table 11 was used to test hypothesis $5\left(\mathrm{H}_{\mathrm{O}}\right)$. The result shows that an F-ratio of 54.78 with an associated exact probability value of 0.00 was obtained. This exact probability value of 0.00 was less than 0.05 level of significance set as a benchmark for testing the hypothesis and it was found to be significant. The null hypothesis which stated that Family size has no significant influence on deviant behaviours exhibited by primary school pupils in Awgu Education Zone of Enugu State was therefore rejected and inference drawn was that family size has a significant influence on deviant behaviours exhibited by primary school pupils in Awgu Education Zone of Enugu State.

\subsection{Research Question 7}

What are the strategies that will be used to curb deviant behaviours among primary school pupils? 
Table 12. Mean and Standard deviation of the strategies that will be used to curb deviant behaviours among primary school pupils

\begin{tabular}{|c|c|c|c|}
\hline $\mathbf{S} / \mathbf{N}$ & & $\bar{x}$ & $\mathrm{SD}$ \\
\hline 69 & $\begin{array}{l}\text { Organizing orientation or public enlightenment programmes through Parents-Teacher-Association } \\
\text { meeting to educate parents on good parental child-rearing practices. }\end{array}$ & 3.11 & 0.31 \\
\hline 70 & $\begin{array}{l}\text { Assigning functions to children that exhibit deviant behaviours to keep them focus on worthwhile } \\
\text { activities. }\end{array}$ & 3.16 & 0.36 \\
\hline 71 & Rewarding and praising children who have good behaviour. & 3.20 & 0.40 \\
\hline 72 & Assigning models to role play by pupils with deviant behaviours. & 3.48 & 0.50 \\
\hline 73 & $\begin{array}{l}\text { Recommendations of learning materials such as novels for moral character building for pupils with } \\
\text { deviant behaviours }\end{array}$ & 3.13 & 0.34 \\
\hline 74 & $\begin{array}{l}\text { Organizing a group counselling programme in schools and communities to educate children on the } \\
\text { negative influence of deviant behaviours. }\end{array}$ & 3.33 & 0.47 \\
\hline 75 & Imparting the knowledge of assertiveness on pupils to enable them to behave normal. & 3.18 & 0.58 \\
\hline 76 & Administering behaviour modification therapy on pupils so as to help them curb deviant act. & 3.13 & 0.55 \\
\hline 77 & Referral of pupils with deviant act to counselling therapist for rehabilitation. & 3.15 & 0.56 \\
\hline 78 & Giving adequate attention to the child's needs in order to make him feel at home. & 3.30 & 0.47 \\
\hline 79 & Engaging children with home videos that have information on moral ethics. & 3.23 & 0.48 \\
\hline 80 & $\begin{array}{l}\text { Avoid buying gun toys to children so as to discourage them from emulating what they see in } \\
\text { violence media play. }\end{array}$ & 3.31 & 0.48 \\
\hline \multirow[t]{2}{*}{81} & $\begin{array}{l}\text { Avoid supporting a child when he or her is at fault in a misunderstanding with his peers in order not } \\
\text { to incite him/her into deviant act. }\end{array}$ & 3.43 & 0.51 \\
\hline & Grand Mean & 3.22 & 0.23 \\
\hline
\end{tabular}

Result in Table 12 shows the mean and standard deviations of respondents on the strategies that will be used to curb deviant behaviours among primary school pupils. Table 12 indicates that the mean values for the items ranged from 3.11 (item 69) to 3.48 (item 72) for the strategies that will be used to curb deviant behaviours among primary school pupils. All the items mean values were above 2.50 criterion value. The cluster grand mean value was 3.22 and also above the criterion value. This implies that primary school pupils agreed that all the strategies can be used to curb deviant behaviours.

\section{Discussion}

\subsection{Types of Deviant Behaviours Exhibited by Primary School Pupils}

The findings showed that out of the 15 types of deviant behaviours such as indulging in exam malpractices, not devoted to studies, bullying weaker students, fighting among pupils, and lateness to school among others that were identified, 12 were exhibited by primary school pupils. The findings were in agreement with the assertion of Ibia (2006) who posited that deviant behaviours in schools include stealing, fighting, examination malpractices, rioting, Telling lies, and destruction of public properties. These are common damnable acts found among the primary school pupils. For instance, fighting is a major form of deviance among pupils. The findings were also in accordance with Richard (2009) who asserted that deviant behaviour is the act of being different from the popular belief usually in a bad way and the opinion of Wisegeek (2013) that deviant behaviour is a behaviour which does not adhere to widely accepted social or cultural norms. Highlighting further, the author maintained deviant behaviour is behaviour that fails to match up to the normal standards that society prescribes as a set of norms for the members.

\subsection{Relationship Between Authoritarian Family Leadership Style and Deviant Behaviours Exhibited by Primary School Pupils}

The findings of the study indicated that the authoritarian family leadership style had a significant relationship with pupils' deviant behaviours. This is in consonance with the postulation of Beyers and Gossens (2003) who stated that parents who adopt authoritarian family leadership style may be linked with negative behavioural outcomes on their children which include aggressive behaviour, decreased emotional functioning, depression and 
lower level of self-confidence. The finding is also in line with the assertion of Terry (2004) who stated that authoritarian parents place firm limits and controls on the children and allow little verbal exchange. In corroboration of the above view, Tim (2007) asserted that authoritarian parents are less responsive to their children's needs, and are more likely to spank a child rather than discuss the problem. Stressing further, the author stated that authoritarian parents display little warmth and are highly controlling. For instance, authoritarian parents exercise authority such as "you will do this because I said so" and "because I'm the parent and you are not". As a result, children may become rebellious and might display aggressive behaviours and as well may become dependent.

\subsection{Relationship Between Authoritative Family Leadership Style and Deviant Behaviours Exhibited by Primary School Pupils}

The findings of the study also revealed that the authoritative family leadership style had a significant relationship with pupils' deviant behaviours. This style marks the parents understanding of how their children are feeling and teaching them how to regulate feelings. Authoritative family leadership style also called assertive, democratic or balanced family leadership style is characterized by a child-centred approach that holds high expectations of maturity (Dienye \& Oyet, 2011). Buttressing further, the authours stated that the authoritative family leadership style understands their children's feeling and teaches them how to regulate them. According to Santrock (2006) children of authoritative parents tend to be cheerful, self-reliant, self-controlled, friendly and achievement-oriented, co-operate with adults and cope well with stress. According to Bystritsky (2006) authoritative family leadership style tends to associate with positive behavioural outcomes which include increased competence, autonomy, self- esteem as well as better problem-solving skills, better academic performance and better peers relations. They encourage children to be independent but still places limits and controls on their actions (Tim, 2007). Highlighting further, Tim stated that authoritative parents set limits and demand maturity, but when punishing a child, the parents will explain the motive for their punishment and children under this type of family leadership style tend to display positive behaviour.

\subsection{Relationship between Permissive Family Leadership Style and Deviant Behaviours Exhibited by Primary School Pupils}

The result of this study is indicative of the fact that the permissive family leadership style had a significant relationship with pupils' deviant behaviours. This result is in agreement with the opinion of Terry (2004) who postulated that permissive family leadership style is related to future deviant and aggressiveness, poor supervision, neglect and indifference, and may play a critical role in engaging in future deviant. Stressing further, Terry maintained that this type of family leadership style demands little in terms of obedience and respect for authority, they are non-traditional and lenient and do not require mature behaviour, allow considerable self-regulation and avoid confrontations. The findings are also in consonance with the assertion of Miller, Diorio and Dudley (2002) who stated that children from permissive homes tend to have a higher frequency of involvement in deviant behaviours such as stealing, fighting, school misconduct and emotional non-conforming behaviour. Also in accordance with this finding is the view of Santrock (2006) who opined that children of permissive parents tend to be domineering, egocentric, non-complaint rebellious, low in self- reliance and self-control, exhibit poor impulsive control, aggressive, aimless, and low in achievement and have difficulties in peer relations.

\subsection{Relationship Between Neglectful Family Leadership Style and Deviant Behaviours Exhibited by Primary School Pupils}

Also, the result of this study shows that neglectful family leadership style had a significant relationship with pupils' deviant behaviours. The findings are in agreement with the assertion of Santrock (2006) who stated that parents in this style do not establish rules nor do they care the direction of the child's behaviour. Children who experience parents neglect develop the sense that other aspects of the parents live are more important than they are. The finding is also in line with the opinion of Mounts (2002) who opined that children of neglectful parents may show patterns of truancy and deviancy, with neglectful family leadership style; children tend to look for acceptance in other places and associate with peer groups with similar family backgrounds.

4.6 Influence of Family Size on Deviant Behaviours Among Primary School Pupils

The findings of the study indicated that family size had an influence on deviant behaviours. The findings are in agreement with the assertion of Bjorklund (2004) who posited that family size is referred to all siblings present in a household. The findings are also in consonance with the assertion of Arthur (2005) who stated that family is regarded as a large size if its family members are within 7-10 and above 10 while family is regarded as small size if its family members are within 1-3 and 4-6 and there is the tendency that the larger the family size the 
likelihood of the children to exhibit deviant behaviours who asserted that a large number of siblings might increase the risk of a child's deviance. Generally as the number of children in a family increases, the amount of parental attention that can be given to each child decreases. This suggests that household overcrowding might be an important intervening factor between family size and deviance.

\subsection{Strategies That Will Be Used to Curb Deviant Behaviours Among Primary School Pupils}

The findings of the study indicated that all the strategies identified can be used to curb deviant behaviours. The results are in agreement with the opinion of Albert and Emmons (2001) who stated that assertive training is a form of behaviour therapy designed to help people (pupils) stand up for themselves, to empower themselves, in more contemporary terms in such that deviant behaviours and other anti-social behaviours will be averted. According to Onwuasoanya (2006), assertive training is a preferred approach for individuals who have difficulty in the appropriate expression of various anxiety or exhibiting deviant behaviours. According to Lipsey and Cullen (2007), cognitive-behavioural therapy is a technique that is used on its own, it uses exercises and instruction that are designed to alter the dysfunctional thinking patterns exhibited by many offenders (pupils). Stressing further, the authors stated that this technique helps pupils become aware of the existence of dysfunctional thinking patterns such as disruptive behaviours, or negative thoughts, attitudes expectations and beliefs, and to understand how negative thinking patterns contribute to unhealthy feelings and behaviours (Wolfe, 2007). Justifying the above ideas, Gootman (2008) stated that rules give pupils a concrete direction to ensure that teachers' expectation becomes a reality when they become consistent in enforcing the rules and procedures made.

The result in Table 3 the null hypothesis which stated that Authoritarian family leadership style has no significant relationship with deviant behaviour exhibited by primary school pupils in Awgu Education Zone of Enugu State was therefore rejected and inference drawn was that, Authoritarian family leadership style has a significant relationship with deviant behaviours exhibited by primary school pupils in Awgu Education Zone of Enugu State. The result in Table 5 the null hypothesis which stated that Authoritative family leadership style has no significant relationship with deviant behaviours exhibited by primary school pupils in Awgu Education Zone of Enugu State was therefore rejected and inference is drawn was that, Authoritative family leadership style has a significant relationship with deviant behaviours exhibited by primary school pupils. The result in Table 7 shows that the null hypothesis which stated that permissive family leadership style has no significant relationship with deviant behaviours exhibited by primary school pupils in Awgu Education Zone of Enugu State was therefore rejected and inference drawn was that permissive family leadership style has a significant relationship with deviant behaviours exhibited by primary school pupils in Awgu Education Zone of Enugu State. The result in Table 9 shows that the null hypothesis which stated that neglectful family leadership style has no significant relationship with deviant behaviours exhibited by primary school pupils in Awgu Education Zone of Enugu State was therefore rejected and inference drawn was that neglectful family leadership style has a significant relationship with deviant behaviours exhibited by primary school pupils. The result in table 10 shows that the null hypothesis which stated that Family size has no significant influence on deviant behaviours exhibited by primary school pupils in Awgu Education Zone of Enugu State was therefore rejected and inference drawn was that, Family size has a significant influence on deviant behaviours exhibited by primary school pupils.

\section{Conclusion}

From the findings of the study, the following conclusions were drawn; the responses of the pupils and their analysis presented the result which indicated that authoritative family leadership style also called assertive, democratic or balanced family leadership style which is expected to have had positive relationship on primary school pupils deviant behaviours showed negative relationship consequently because parents failed to use it in their child-rearing and upbringing practices. The authoritarian, permissive and neglectful family leadership styles which were consistently applied by parents presented significant negative relationship on primary school pupil's deviant behaviours in Awgu Education Zone of Enugu State.

\section{CompetingInterestsStatement}

Theauthorsdeclarethattherearenocompetingorpotentialconflictsofinterest.

\section{References}

Albert, R., \& Emmons, M. (2001). Your perfect Assertiveness and Equality in your Life and Relationships (8th ed.). Atascadero CA: Impact Publishers Inc.

Annick, P. (2002). Leadership Styles. Retrieved from www.soencouragement.org/leadership-styles.html 
Anyanwu, J. I., \& Ofordile, C. (2012). Marriage and family: Issues, problems and counseling strategies. Snaap Press Ltd Enugu.

Arthur, J. L. (2005). Family size and its socio-economics implications in sunyani municipality of the brongahafo region of Ghana, West Africa (Unpublished doctoral thesis). University of cape coast, Ghana.

Baumrind, D. (1972). Current patterns of parental authority. Developmental psychology monographs, 4(1, pt.2). https://doi.org/10.1037/h0030372

Benokraitis, N. (2008). Marriages and families (6th ed., P. 271.).

Beyers, W., \&Gossens, L. (2003). Psychological separation and adjustment to university: Moderating effects of gender, age and perceived parenting style. Journal of Adolescent Research, 18(4), 363-382. https://doi.org/10.1177/0743558403018004003

Bjorklund, A., Eriksson, T., Janti M. Raaum, O., \& Osterbacka, E. (2004). Family structure and labor market success: the influence of siblings and birth order on the earnings of young adults in Norway, finland, and Sweden.In M.Corak, (ed.), Generational income mobility. Cambridge: Cambridge university press.

Bruns, B., Mingat, A., \& Rakotomalala, R. (2003). Achieving Universal Primary Education by 2015.A chance for every child. Washington D.C: The World Bank.https://doi.org/10.1596/0-8213-5345-4

Bystritsky, M. (2006). Relations among attachment quality, parenting style, quality of the family environment and social adjustment. Dissertation Abstracts International: Section B: The Science \& Engineering, 60(12B), 6395.

Cheng, J. (2001). Family violence victimization as an influential cause to juvenile deviance. Journal of Criminology, 8, 215-246.

Department of statistics of ministry of the interior. (2010). Number of villages, neighborhoods, households and resident population in Taiwan. Retrieved from http://sowf.moi.gov.tw/stat/month/m1-01.xls

Dienye V. U., \& Oyet, N. I. (2011).Effects of parenting styles on deviant behaviours among young people in Adoni tribe. African Journal of Social Sciences, 1(3), 107-117.

Farrington, D. P., \& Loeber, R. (1999). Tranatlanticreplicability of risk factors in the development of delinquency. In P. Cohen, C. Slomkowski, \& L. N. Robins (Eds.), Historical and geographyical influences on psychopathology (pp.299-329). Mahwah, NJ: Lawrence Erlbaum.

Goode, E. (2005). The diversity form of deviance.An introduction to the study of deviance and social control. Retrieved from https://us.sagepub.com/en- us/nam/upm- data/47451_Chapter_3.pd

Gootman, M.E. (2008). The caring teacher's guide to discipline: helping students learn self-control, responsibility, and respect, $K$-6(P. 3).

Henderson, T., \& Mapp, L. (2002).A new wave of evidence: The impact of school, family and community connections on student achievement. Austin, TX: National center for Family and Community Connection with Schools.

Ibia, E. I. (2006). Sociological foundations of Nigeria education. Uyo, Nigeria: On'pex publisher.

Kantarevic, J., \& Mechoulan, S. (2006). Birth order, educational attainment and earnings, an investigation using the PSID. The Journal of Human Resources, XLI(4), 755-777.https://doi.org/10.3368/jhr.XLI.4.755

Okonkwo. (2005). Parenting style and adolescent belomini. Awka: Education Press.

Kendra, C. (2015). Theories of deviant bevaviour. Retrieved from http://psychology.about.com/od /developmentalpsychology/a/devissues.htm

Kopko, K. (2007). Parenting styles and Adolescents. Retrieved from http://www.human.cornel.edu/pam/eutreach/parenting/research/uploadparening-20stylesand20Adolescents. PDF

Lipsey, M. W., \& Derzon, J. H. (1998). Predictors of violent or serious delinquency in adolescence and early adulthood: A synthesis of longitudinal research. In R. Loeber and D.P. Farrington (Eds.), Serious and violent juvenile offenders: Risk factors and successful interventions (pp.86-105). Thousand Oaks, CA: Sage. https://doi.org/10.4135/9781452243740.n6

Macionis, J. J. (2007). Society the basics. New Jersey. Pearson prentice Hall, Inc.

Merriam, W. (2013). Full definition of behaviour. Retrieved from 
www.merriamWebster.com/dictionaryy/behaviour

Miller, J. M., Diorio, C., \& Dudley, W. (2002). Parenting style and adolescents reaction to conflict: Is there a relationship. Journal of Adolescent Health, 31(6), 463-468. https://doi.org/10.1016/S1054-139X(02)00452-4

Mounts, N. S. (2002). Parental management of peer relationships in context: The role of parenting style. Journal of family psychology, 16(1), 58-69. https://doi.org/10.1037/0893-3200.16.1.58

Murray, J., \& Farrington, D. P. (2005). Parental imprisonment: Effects on boys' antisocial behaviour and delinquency through the life-course. Journal of child psychology and psychiatry, 46(26), 1269-1278. https://doi.org/10.1111/j.1469-7610.2005.01433.x

Ngale, I. F. (2009). Family structure and juvenile delinquency: Correctional Centre Betamba, Centre Province of Cameroon (pp. 1-18). Retrieved from: www.internetjournalofcriminology.com

Nwachukwu, V. C. (2001).Psychological fundamental in Nigerian education. Owerri: Whyte and Whyte Press.

Nwankwo, H. (2006). Youth deviant behaviour in West Africa. Yale. Haven.

Nzekwu, V. (2011). Forms of indiscipline and deviant behaviours among persons. Retrieved from http://www.infobarrel.com>University

Okpako, J. E. F. (2004). Parenting the Nigeria adolescents towards smooth transition to adulthood. In C. I., Nwawoke, O. A., Bangbuse, \& A. Mnokola, (Eds.),Contemporary issue and research in adolescents. Ibadan: Onwade Printing Press.

Onwuasoanya, P. N. (2008).Behaviour modification techniques counselling. Nsukka, Nigeria: Great AP Express Publishers.

Richard, N. (2009). Deviant behaviours -definition, examples, types. Retrieved from http://www.voices.yahoo.com/deviant-behaviour-definition- examples-types- 4956514,html?cat=9.

Sanjana, A. (2008). Social problem: Act deviance and criminal activity. Retrieved from: $\mathrm{http} / / / \mathrm{www}$.protagonize.com/story/social-problem-act-of-deviance-and-criminal-activity

Santrock, J. W. (2006). Life-span development. New York: The McGrow-Hill company, Inc.

Shankar R., C. N. (2012). Sociology: Principles of sociology with an introduction to social thought. India: RajindraRavindra Printers Ltd.

Sunil, P. (2011). Five most primary functions of a family. Retrieved from http//www.preservearticles.com./---5-most-primary-functions-of-a-family.html

Terry, D. J. (2004).Investigating the relationship between parenting styles and deviant behaviours. Retrieved from http://www.scholarworks.gvsu.edu/menair/vol8/iss/11

Tim, G. (2007). No Fear: Growing up in a Risk Averse Society. CalousteGulbenkian Foundation

Toby, C. (2015). The 4 essential type of family structure. Retrieved from http://EzineArticles .com/?expert=Toby_Shelton

Umemetu, U., \& Ogbonna, N. (2013). Supervision and inspection of primary education in Nigeria: Strategies for improvement. Academic Research Internationa, 11(4), 4. Retrieved from www.savap.org.pk

UNESCO. (2001). Primary Education: The core of development and progress. UNESCO Education Webmaster.

Wisegeek. (2013). What is deviant behaviour? Retrieved from http://www.wisegeek.org/what-is-deviant-behaviour.html

Wolfe, D. A. (2007). Acting out: understanding and reducing aggressive behaviour in children and Youth. Toronto: Centre for Addiction and Mental Health.

\section{Copyrights}

Copyrightforthisarticleisretainedbytheauthor(s), withfirstpublicationrightsgrantedtothejournal.

Thisisanopen-accessarticledistributedunderthetermsandconditionsoftheCreativeCommonsAttributionlicense(http: //creativecommons.org/licenses/by/4.0/). 